
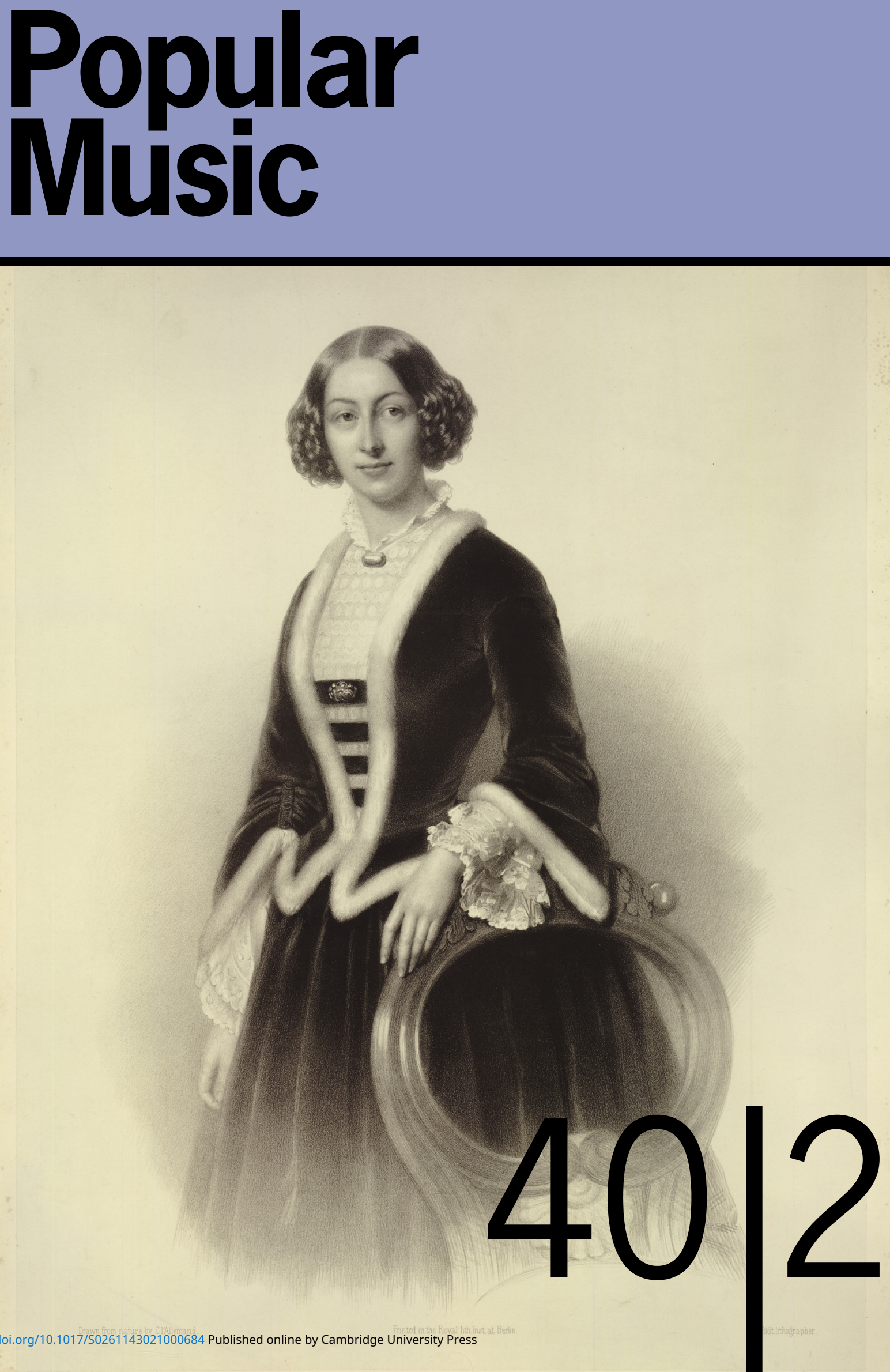
Editorial Group

MARTIN CLOONAN (Co-ordinating Editor)

NANETTE DE JONG

DAI GRIFFITHS

SARAH HILl (Co-ordinating Editor)

BARBARA LEBRUN (Book Review Editor)

\section{Founding Editors}

DAVID HORN

RICHARD MIDDLETON

\section{International Advisory Editors}

Christopher Ballantine (South Africa)

Nicole Biamonte (Canada)

Alf Björnberg (Sweden)

Barbara Bradby (Ireland)

Sara Cohen (UK)

Anne Danielsen (Norway)

Nicola Dibben (UK)

Franco Fabbri (Italy)

Murray Forman (USA)

Héctor Fouce (Spain)

Simon Frith (UK)

Juan Pablo González (Chile)

Lucy Green (UK)

Line Grenier (Canada)

Jill Halstead (Norway)

Stan Hawkins (Norway)

(C) Cambridge University Press 2021
KEITH NEGUS

TOM PERCHARD

JOHN STREET

CATHERINE TACKLEY

Popular Music is an international multi-disciplinary journal covering all aspects of the subject - from the formation of social group identities through popular music, to the workings of the global music industry, to how particular pieces of music are put together. The journal includes all kinds of popular music, whether rap or rai, jazz or rock, from any historical era and any geographical location. Popular Music carries articles by scholars from a variety of disciplines and theoretical perspectives. Each issue contains substantial, authoritative and influential articles, topical pieces, and reviews of a wide range of books. Some issues are thematic. The editors also welcome polemical pieces for the 'Middle Eight' section of the journal. Contributors should consult the 'Notes' on the inside back cover.

Articles and any other material not related to reviews should be submitted online at cambridge.org/pmu. Any queries relating to submissions may be addressed to popularmusic@cambridge.org. Material for review should be sent to Dai Griffiths, email dmgriffiths@brookes.ac.uk.

Subscriptions Popular Music (ISSN 0261-1430) is published four times a year in February, May, October and December. Four parts form a volume. The subscription price (excluding VAT) for Volume 40 which includes print and electronic access to institutional subscribers is $£ 465$ (USA, Canada and Mexico \$794); print only for individuals is $£ 78$ (USA, Canada and Mexico \$119). Single parts cost $£ 131$ (USA, Canada and Mexico \$215). An online only price is available to institutional subscribers for $£ 400$ (USA, Canada and Mexico \$669). EU subscribers (outside the UK) who are not registered for VAT should add VAT at their country's rate. VAT registered subscribers should provide their VAT registration number. Orders, which must be accompanied by payment, may be sent to a bookseller, subscription agent or direct to the publisher: Cambridge University Press, Journals Fulfillment Department, University Printing House, Shaftesbury Road, Cambridge CB2 8BS, UK. Orders from the USA, Canada and Mexico should be sent to Cambridge University Press, 1 Liberty Plaza, Floor 20, New York, NY 10006, USA. Japanese prices for institutions are available from Kinokuniya Company Ltd, P.O. Box 55, Chitose, Tokyo 156, Japan. Prices include delivery by air.

Claims for missing issues should be made immediately on receipt of the subsequent issue.

Copying This journal is registered with the Copyright Clearance Center, 222 Rosewood Drive, Danvers, MA 01923. Organizations in the USA who are also registered with the C.C.C. may therefore copy material (beyond the limits permitted by sections 107 and 108 of US copyright law) subject to payment to C.C.C. of the per copy fee of $\$ 12.00$. This consent does not extend to multiple copying for promotional or commercial purposes. Code 0261$1430 / 2013 \$ 12.00$. Organizations authorized by the Copyright Licensing Agency may also copy material subject to the usual conditions.

ISI Tear Sheet Service, 3501 Market Street, Philadelphia, Pennsylvania 19104, USA, is authorized to supply single copies of separate articles for private use only.

For all other use, permission should be sought from the Cambridge or New York offices of Cambridge University Press.

INTERNET ACCESS This journal is included on Cambridge Core at cambridge.org/core. For further information on Popular Music and all other Cambridge journals see http:/ / www.cambridge.org.

Front cover: Johanna Wagner, mezzo-soprano (1828-1894). (c) The Trustees of the British Museum. 


\section{The Contributors}

Susie Khamis is Senior Lecturer in Public Communication at the University of Technology Sydney. Her research areas are branding, representations of cultural diversity and consumer cultures. She has published widely in these areas and her current research focuses on how successful brands survive through global crises. She is the author of Branding Diversity (Routledge 2020).

BRENT KeOGH is a Lecturer in Music and Sound Design at the University of Technology Sydney. His current research interests include music and environmental justice, immersive audio/visual technologies and sonic branding. Keogh is also a musician and composer, performing on the mandolin, middle eastern lute (oud), guitar and vocals. He studied the Egyptian oud with awarded musician Joseph Tawadros and classical mandolin with Israeli conductor/mandolinist Alon Sariel and Fiona Horbach.

Olivia R. LucAs is Assistant Professor of Music Theory at Louisiana State University. Her work focuses on analysis of extreme metal music and spans approaches from musicology, ethnomusicology and sound studies. She has published work in Music Theory Online, Popular Music and the Journal of Sonic Studies. She holds a PhD in music theory from Harvard University, and previous appointments include Victoria University of Wellington (Aotearoa New Zealand) and the University of Iowa.

Phoebe Macrossan has a Bachelor of Journalism/Bachelor of Arts degree from the University of Queensland, as well as a Bachelor of Arts (Hons) and a Doctor of Philosophy (PhD) from the University of New South Wales. Her doctoral thesis examined the development of the American screen musical across film, television, music video and YouTube forms during the 21st century. Dr Macrossan's research interests are evolving digital screen formats and debates, with a focus on the intersections between popular music, screen studies, and new media. She has published on the Beatles jukebox musical Across the Universe, musical television series Crazy Ex-Girlfriend and Nashville, and Beyoncé's visual albums.

ERNEST OWUSU-POKU is a Ghanaian musician trained on piano/synthesiser, gyil (traditional xylophone), bass guitar, and traditional drumming, as well as sound recording, record production, and Ghanaian sound scholarship. He is currently a second-year MPhil student at the University of Ghana's Department of Music, researching the social history of Ghana's record industry.

ANDREI SORA is an independent researcher. He has published work on expressivity and the instrumental persona, synthwave, and music in communist and post-communist Romania, and has taught Global Hip-Hop, the History of Electronic Music, and Scenes and Subcultures at the University of Oxford. 
ii The Contributors

Matt Stahl is Associate Professor of Information and Media Studies at the University of Western Ontario. He received his PhD in Communication in 2006 at the University of California, San Diego. His first book, Unfree Masters: Recording Artists and the Politics of Work, was published in 2012 by Duke University Press. 